\title{
PERSPECTIVE
}

\section{Human T lymphotropic virus type 1 uveitis}

\author{
Manabu Mochizuki, Kazuo Tajima, Toshiki Watanabe, Kazunari Yamaguchi
}

\section{Retroviruses and human diseases}

Retroviruses are RNA viruses, encoding for an RNA-dependent DNA polymerase (reverse transcriptase) which translates the viral RNA into a DNA provirus, which in turn is rapidly integrated into the cell genome. ${ }^{1}$ The provirus then faces three options: (1) to remain latent in the infected cells when the host is able to inhibit the transcription of the viral genes; (2) to enter a replicating cycle leading to the production of viral progeny and death of the infected cells when the host is unable to control the viral genes; and (3) to develop a physiopathological cell-virus interaction leading to transformation and clonal proliferation of the infected cells. ${ }^{1}$ Retroviruses are currently classified into oncoviruses and lentivirusès. Oncoviruses are associated with haematological proliferations and tumours of the connective tissues in many animal species. In humans, this family is represented by human T lymphotropic virus type 1 (HTLV-I), which is known as the causative virus of $\mathrm{T}$ cell malignancies, ${ }^{2-8}$ chronic progressive myelopathy, ${ }^{9-23}$ and uveitis, which will be discussed later. A related virus, HTLV type 2 (HTLV-II), is known to be endemic in some regions of the world, though its relevance to human diseases is not proved. The second family of retroviruses, lentiviruses, induce chronic and progressive pulmonary and/or neurological diseases in a number of animal species. In humans, a retrovirus previously known as HTLV-III is the representative of this family. ${ }^{1}$ The virus has been shown to be the causative agent of acquired immunodeficiency syndrome (AIDS) and is now named human immunodeficiency virus (HIV-I and HIV-II). Retroviruses have existed from ancient times, but the diseases caused by these human retroviruses have been recognised only recently. Evidence indicating the significant role of these viruses in human diseases has been forthcoming from clinical and basic research employing immunological and molecular biological techniques. These studies have provided important insights into the profound health implications of the human retroviruses worldwide. This is also true in ophthalmology, where many current reports have shown that both human retroviruses, HTLV-I and HIV, play a significant role in ocular diseases, particularly uveitis.

The spread of HIV, and its subsequent fatal consequences of AIDS, has produced a number of ocular abnormalities. The clinically important pathogenic effects of HIV on ocular tissues are produced by the infection of CD4 T cells and subsequent death of HIV-infected CD4 T cells, which results in immunodeficiency, thereby leading to opportunistic infection. Cytomegalovirus (CMV) retinitis is the most common ophthalmic opportunistic infection in AIDS and has the worst visual prognosis. The other intraocular opportunistic infections in AIDS patients are toxoplasmosis, syphilis, tuberculosis, Candida, Cryptococcus, Pneumocystis carinii, herpes zoster, and herpes simplex viruses. Although some of these disorders, including ocular toxoplasmosis and acute retinal necrosis syndrome, may occur in healthy individuals, the inflammation is much more rapid and intense when it occurs in patients with AIDS, and the majority of these diseases occur only in cases of immunodeficiency such as AIDS. Whenever patients with these opportunistic infections present, therefore, one should consider infection with HIV.

HTLV-I and HTLV-II: their relevance to systemic diseases

In 1980, Gallo and his colleagues first isolated a retrovirus from the cultivated tumour cells of a patient with then diagnosed cutaneous lymphoid malignancy. This virus was named human T lymphotropic virus type 1 (HTLV-I). ${ }^{2}$ In parallel, the epidemiological observation of $\mathrm{T}$ cell malig-
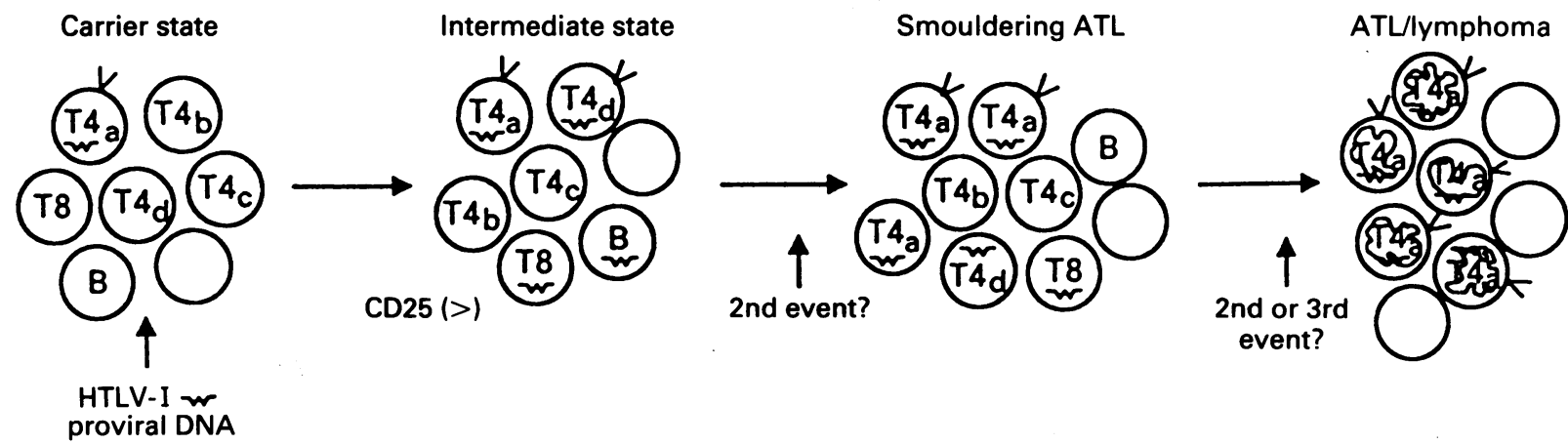

HTLV-I proviral DNA

$\begin{array}{cc}\text { Not } & \begin{array}{c}\text { Polyclonal } \\ \text { integration }\end{array}\end{array}$

Monoclonal integration

\section{Infected cells in peripheral blood}

Major population normal WBC
Monoclonal integration (malignant transformation) 


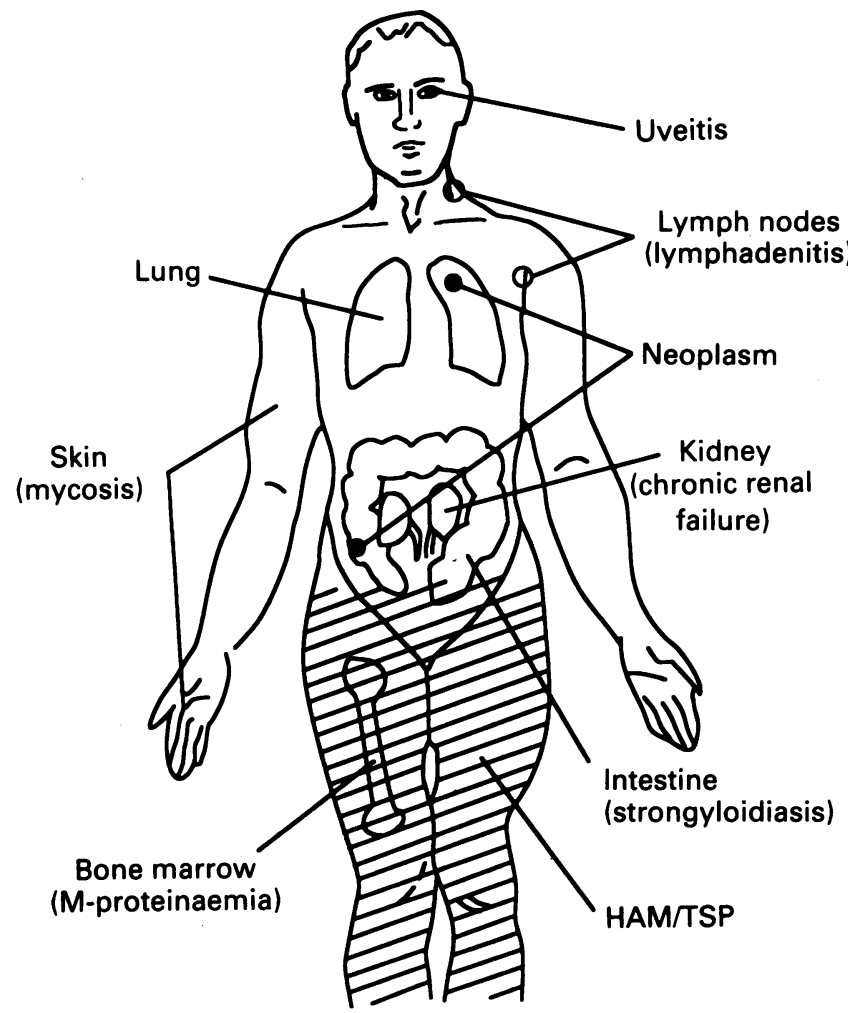

Figure $2 H T L V$-I related diseases $; H A M=H T L V-I$ associated myelopathy; TSP = tropical spastic paraparesis (published with permission).

nancies (adult $T$ cell leukaemia/lymphoma [ATL]) with clusters of cases in the southwestern islands of Japan (Kyushu and Shikoku) suggested the involvement of an infectious agent, probably of a viral nature, in these $T$ cell malignancies. ${ }^{34}$ Studies using molecular biological techniques have shown the presence of a provirus in ATL cells which is identical to HTLV-I. ${ }^{5-1}$ A putative sequence of events in HTLV-I lymphomagenesis is illustrated in Figure $1 .^{8}$

Recent studies have suggested that HTLV-I is related to many other diseases, such as chronic myelopathy, uveitis, and lymphadenitis, and also HTLV-I infection can be a risk factor of neoplasms, as summarised in Figure 2 (see a review by Takatsuki et $a l^{8}$ ). The majority of these are not $\mathrm{T}$ cell malignancies, but are classified as inflammatory disorders. The neurological manifestations of HTLV-I infection were first reported in 1984 by Gessain et al, who reported a high seroprevalence of the virus in patients suffering from a chronic myelopathy of unknown aetiology, named tropical spastic paraparesis (TSP). ${ }^{9}$ This was confirmed in patients suffering from similar neurological symptoms in Jamaica, ${ }^{10}$ and in the HTLV-I endemic island of Kyushu in Japan," where the disease was named HTLV-I associated myelopathy (HAM). In addition to the epidemiological evidence, a causal role for HTLV-I in HAM/TSP is suggested by: (1) the presence of specific antibodies to and molecular fingerprints for HTLV-I in the blood and cerebrospinal fluid (CSF) ${ }^{12}$; and (2) isolation of HTLV-I from peripheral blood and CSF. ${ }^{13}$ The pathogenic mechanisms by which HTLV-I induces the neurological disorder are not yet fully understood. However, involvement of immune mediated mechanisms is suggested on the basis of the following observations in patients with HAM/TSP: (1) higher mean titre of antibody to HTLV-I, ${ }^{14}$ elevated levels of interleukin $6,{ }^{15}$ and increased number of activated $\mathrm{T}$ cells and $\mathrm{CD} 4^{+}$cells $^{16}$ in the peripheral blood and CSF; (2) higher mean levels of spontaneous proliferation of peripheral T cells ${ }^{17} ;(3)$ expression of interleukin 2 receptors on the cell surface of HTLV-I infected T cells ${ }^{18}$; and (4) favourable response to corticosteroids. ${ }^{19}$ As opposed to ATL, HAM/TSP is not a $\mathrm{T}$ cell malignancy, but rather an inflammatory disorder, despite the fact that both diseases are aetiologically related to HTLV-I. This, then, raised a question as to whether the causative virus of both diseases is identical. The proviruses detected from HAM/TSP and ATL were found to be identical by Southern blotting ${ }^{120}$ and the nucleotide sequence analysis of the provirus from HAM/TSP had ' $(>97 \%)$ ' homology to that of ATL..$^{21}$ Although the viruses isolated from ATL and HAM/TSP have identical genomic composition, patients suffering from both ATL and HAM/TSP are very rare. There are a few such cases reported. ${ }^{22}{ }^{23}$ Environmental and host factors may therefore play a role in determining which HTLV-I infected individuals develop haematological or neurological disease.

HTLV-I is transmitted through the following three routes: (1) breast feeding, (2) blood transfusion (only by cellular components), and (3) sexual contact, both heterosexual primarily from men to women and male homosexual. ${ }^{24}$ Worldwide epidemiological studies of HTLV-I have demonstrated that the main endemic groups for HTLV-I in the world are Japanese of southern Japan and black people in central Africa and the Caribbean basin (Fig 3). In Japan, the

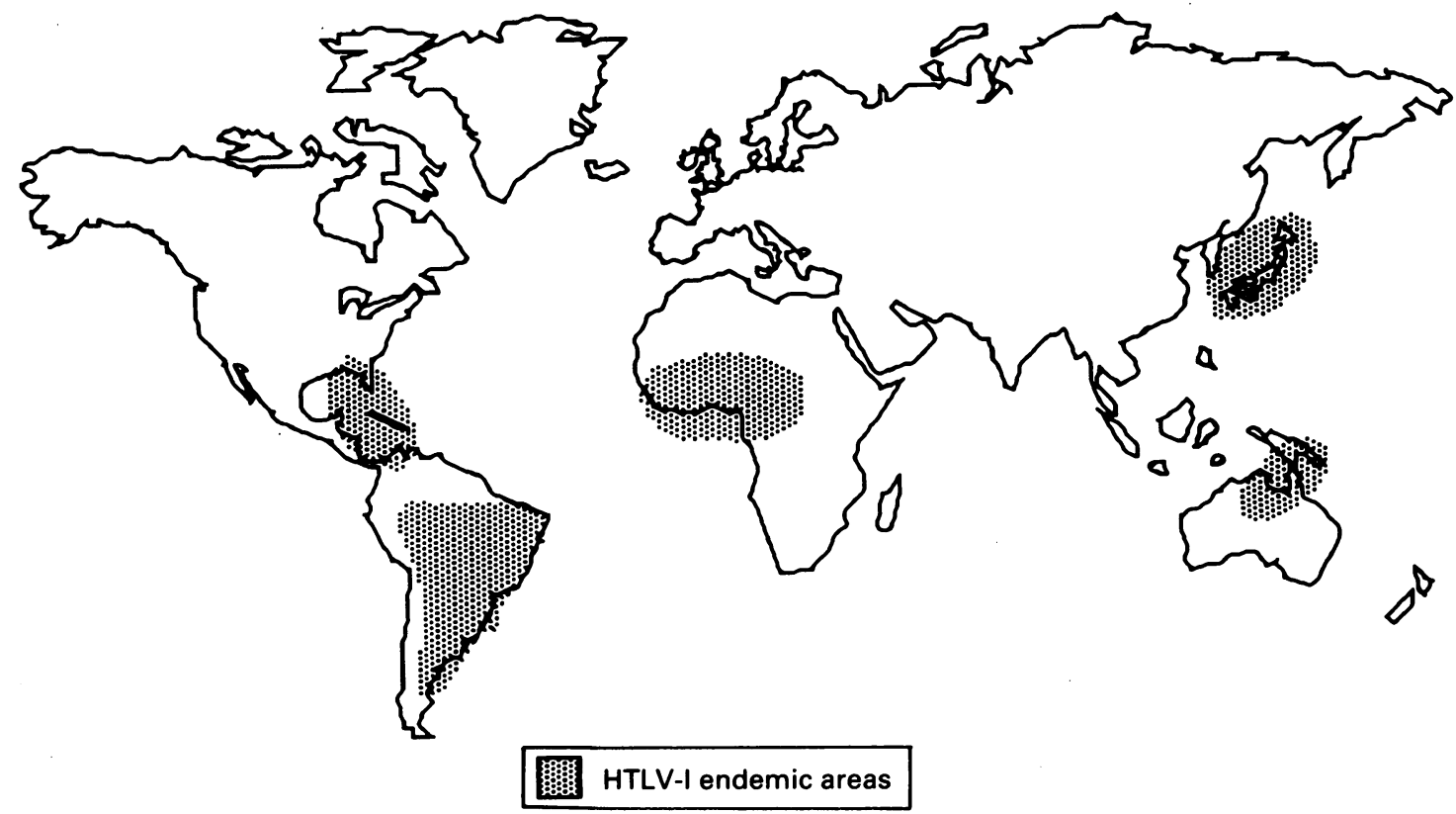

Figure 3 Worldwide distribution of HTLV-I. 
virus is endemic in the southwestern islands of Kyushu (Miyazaki, Kagoshima, and Okinawa). ${ }^{25}$

A related virus, HTLV-II, was first isolated from the transformed $\mathrm{T}$ cells of a patient with so-called hairy cell leukaemia in the United States. ${ }^{26}$ This virus has not yet been proved to be associated with any human diseases. Recent seroepidemiological studies revealed that HTLV-II is mainly found among native Indian populations throughout the Americas ${ }^{27}$ and has rapidly spread among injecting drug users in the United States. ${ }^{28}$ Because HTLV-II cannot be distinguished from HTLV-I by standard serological tests, it is likely that some earlier reports on the seroepidemiology of HTLV-I were confounded by HTLV-II. However, it has become possible to distinguish the two viruses by detection of their specific antigens using methods such as the polymerase chain reaction.

\section{Ocular manifestations in HTLV-I infection}

The first evidence of the implication of HTLV-I in the development of ocular diseases was reported by Ohba and his colleagues, who examined HTLV-I infected patients for their ocular involvement and found CMV retinitis and necrotising retinitis of unknown aetiology in two patients with ATL, and cotton wool spots and/or vitreous opacities in four patients with HAM/TSP and in one asymptomatic carrier. ${ }^{29}$ Later, a number of reports mainly from southern Japan have confirmed that a proportion of HTLV-I infected individuals had ocular manifestations ${ }^{30-34}$ which can be classified into three groups: (1) opportunistic infections and tumoral infiltration in patients with ATL; (2) ocular manifestations in patients with HAM/TSP, including Sjögren's syndrome, retinal pigmentary degeneration, optic atrophy, vitreous opacities, cotton wool spots, and retinal vasculitis; and (3) uveitis in asymptomatic carriers. Despite the accumulation of case reports showing ocular manifestations in HTLV-I infected individuals, the significant association of HTLV-I in ocular diseases had not been proved until a serological study by Nakao and her colleagues, ${ }^{35}$ and seroepidemiological, clinical, and molecular biological studies by Mochizuki and his group..$^{36-42}$

\section{HTLV-I uveitis}

The evidence indicating the significant association of HTLV-I with a certain type of uveitis will be discussed here on the basis of the most recent data from our seroepidemiological, clinical, and molecular biological studies. ${ }^{36-42}$ These studies included various ocular diseases at two hospitals in the island of Kyushu in southwestern Japan: Miyakonojo, located in an HTLV-I endemic area, and Kurume, located in a less endemic area. All patients with uveitis, the diagnosis of which was made from January 1989 and April 1992 at the two hospitals, and all patients who were operated on from April 1991 and April 1992 at the two hospitals with age-related cataract, retinal detachment, glaucoma, or strabismus were the subjects of our study. Patients with ATL and HAM/TSP were excluded from our studies.
SEROEPIDEMIOLOGICAL STUDY

We examined the seropositivity of HTLV-I in various ocular disorders by the particle agglutination assay (Fujirebio, Tokyo) and the enzyme linked immunosorbent assay (ELISA) (Eisai, Tokyo). Samples positive for HTLV-I by both assays were taken as seropositive and those positive by one of the assays were further analysed by western blot assay. The patients examined for the seropositivity consisted of the following three groups: (1) patients with uveitis without defined causes even after extensive systemic and ophthalmic examinations (idiopathic uveitis); (2) patients with uveitis with defined causes such as Behçet's disease, Vogt-KoyanagiHarada's disease, sarcoidosis, toxoplasmosis, and the like; and (3) patients with non-uveitic ocular diseases such as agerelated cataract, glaucoma, retinal detachment, and strabismus. The overall HTLV-I seroprevalence of the three groups was 23\% (157 of 686 patients ) in Miyakonojo and $8 \%$ (44 of 523 patients) in Kurume. In Miyakonojo, the HTLV-I seroprevalence in patients with uveitis with defined causes and that in patients with non-uveitic ocular diseases was $10 \%$ (11 of 106 patients) and 20\% (75 of 395 patients), respectively. The seroprevalence of the virus in both groups increased with the age of the patients (Fig 4). The seroprevalence in the general population in this area was $11 \cdot 5 \%{ }^{43}$ and the seroprevalence of anti-HTLV-I antibody in the general population and in blood donors is known to increase with age. ${ }^{44}$ Therefore, the patients with uveitis with defined causes and the patients with non-uveitic ocular diseases in our study were considered to reflect the general population in this area. Conversely, the seroprevalence of the virus in patients with idiopathic uveitis $(38 \%, 71$ of 185 patients) was much higher than that in the other two groups. More striking was the age distribution of the HTLV-I seroprevalence in idiopathic uveitis (Fig 4): it was much higher in younger patients (aged 20 to 49 years) with idiopathic uveitis (49\%, 37 of 75 patients) than it was in patients with uveitis with defined causes $(12 \%$, six of 50

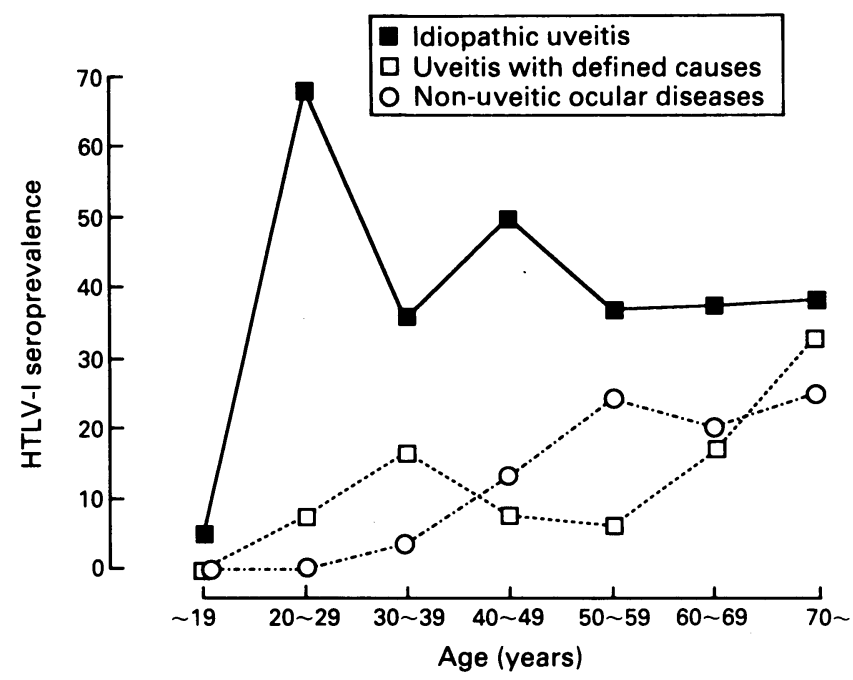

Figure 4 The age distribution of the seroprevalence of HTLV-I in an HTLV-I endemic area (Miyakonojo).

Table 1 Risk of HTLV-I infection for uveitis according to age group in Miyakonojo and Kurume, fapan

\begin{tabular}{|c|c|c|c|c|c|c|c|c|}
\hline \multirow[b]{3}{*}{ Disease } & \multicolumn{4}{|c|}{ Miyakonojo } & \multicolumn{4}{|c|}{ Kurume } \\
\hline & \multicolumn{2}{|c|}{$20-49$ years } & \multicolumn{2}{|c|}{$\geqslant 50$ years } & \multicolumn{2}{|c|}{$20-49$ years } & \multicolumn{2}{|c|}{$\geqslant 50$ years } \\
\hline & $\overline{+l-\dagger}$ & Odds ratio $(95 \% C I) \neq$ & $+1-$ & Odds ratio $(95 \% C I)$ & $+1-$ & Odds ratio $(95 \% C I)$ & $+/-$ & Odds ratio $(95 \% C I)$ \\
\hline $\begin{array}{l}\text { Idiopathic uveitis } \\
\text { Uveitis with defined causes } \\
\text { Non-uveitic ocular diseases }\end{array}$ & $\begin{array}{r}37 / 38 \\
6 / 44 \\
5 / 75\end{array}$ & $\begin{array}{l}14 \cdot 6(5 \cdot 3-40 \cdot 2)^{\star \star} \\
2 \cdot 1(0 \cdot 6-7 \cdot 1) \\
1 \cdot 0\end{array}$ & $\begin{array}{c}33 / 35 \\
5 / 42 \\
70 / 233\end{array}$ & $\begin{array}{l}2 \cdot 0(1 \cdot 2-3 \cdot 3)^{\star} \\
0 \cdot 4(0 \cdot 2-1 \cdot 0) \\
1 \cdot 0\end{array}$ & $\begin{array}{r}14 / 41 \\
5 / 68 \\
1 / 35\end{array}$ & $\begin{array}{l}12 \cdot 0(1 \cdot 5-95 \cdot 5)^{\star} \\
2 \cdot 6(0 \cdot 3-22 \cdot 9) \\
1.0\end{array}$ & $\begin{array}{l}8 / 54 \\
1 / 35 \\
14 / 167\end{array}$ & $\begin{array}{l}1 \cdot 8(0 \cdot 7-4 \cdot 4) \\
0 \cdot 3(0 \cdot 0-2 \cdot 7) \\
1 \cdot 0\end{array}$ \\
\hline
\end{tabular}

$t+/-=$ HTLV-I seropositive/HTLV-I seronegative, $\$ 95 \% \mathrm{CI}$ : $95 \%$ confidence interval.

${ }_{\star \star} \mathrm{p}<0 \cdot 001,{ }^{\star} \mathrm{p}<0.01$
0. 
patients) or in patients with non-uveitic ocular diseases $(6 \%$, five of 80 patients) in the same age group (Table 1). A similar observation was recorded even in the HTLV-I less endemic Kurume, although the seroprevalence in each group was lower than that in Miyakonojo (Table 1). The odds ratio was computed as an estimate of relative risk of HTLV-I infection in the three groups (Table 1). In younger patients (20-49 years), the odds ratio of idiopathic uveitis for HTLV-I infection was estimated at $14 \cdot 6$ (95\% confidence interval [CI]: $5 \cdot 3-40 \cdot 2)$ in Miyakonojo and $12 \cdot 0$ (95\% CI:1.5-95.5) in Kurume. On the other hand, in older patients ( $\geqslant 50$ years), the odds ratio was much lower: $2 \cdot 0(95 \% \mathrm{CI}: 1 \cdot 2-3 \cdot 3)$ and $1 \cdot 8$ (95\% CI: $0 \cdot 7-4 \cdot 4$ ) in Miyakonojo and Kurume, respectively. The odds ratio of uveitis with defined causes for HTLV-I infection in both age groups was very low even in Miyakonojo (Table 1), although because of the definition of the diagnosis, uveitis with defined causes, the majority of individuals with HTLV-I infection tended to be excluded from this group and included in the group with idiopathic uveitis. When stratified by sex, it was found in Miyakonojo that the odds ratio of idiopathic uveitis for HTLV-I infection was relatively uniform, estimated at 10.0 (95\% CI: $2 \cdot 21-44 \cdot 99)$ in males and 14.6 (95\% CI: $4 \cdot 74-45 \cdot 01)$ in females in the younger age group. The odds ratio in the older age group was equally low in both sexes: $1.6(95 \% \mathrm{CI}: 0.71-3.49)$ in males and 1.78 (95\% CI: $1 \cdot 05-2 \cdot 98$ ) in females (Fig 5). This epidemiological finding - that is, a trend for declining odds ratio for HTLV-I with age, is important since the opposite is true for the carriers of HTLV-I in the general population. This implies that early exposure to HTLV-I is important, and the uniform odds ratio when stratified by sex suggests that most transmission that is important for uveitogenesis is prenatal. These epidemiological data indicate that the idiopathic uveitis in asymptomatic carriers of HTLV-I is a distinct clinical entity, like ATL and HAMTSP, and it can be termed HTLV-I uveitis.

Another noteworthy observation in the causal implication of HTLV-I in uveitis is the familial clustering of the disease. We have found two familial cases: (1) a 62-year-old woman and her 66-year-old sister, and (2) a 52-year-old woman and her 26-year-old daughter. ${ }^{40}$ All the patients were suffering from uveitis characterised by dense vitreous opacities with mild iritis and mild retinal vasculitis and had negative results on systemic and ophthalmic examinations except for a seropositive response to HTLV-I. None of the patients had

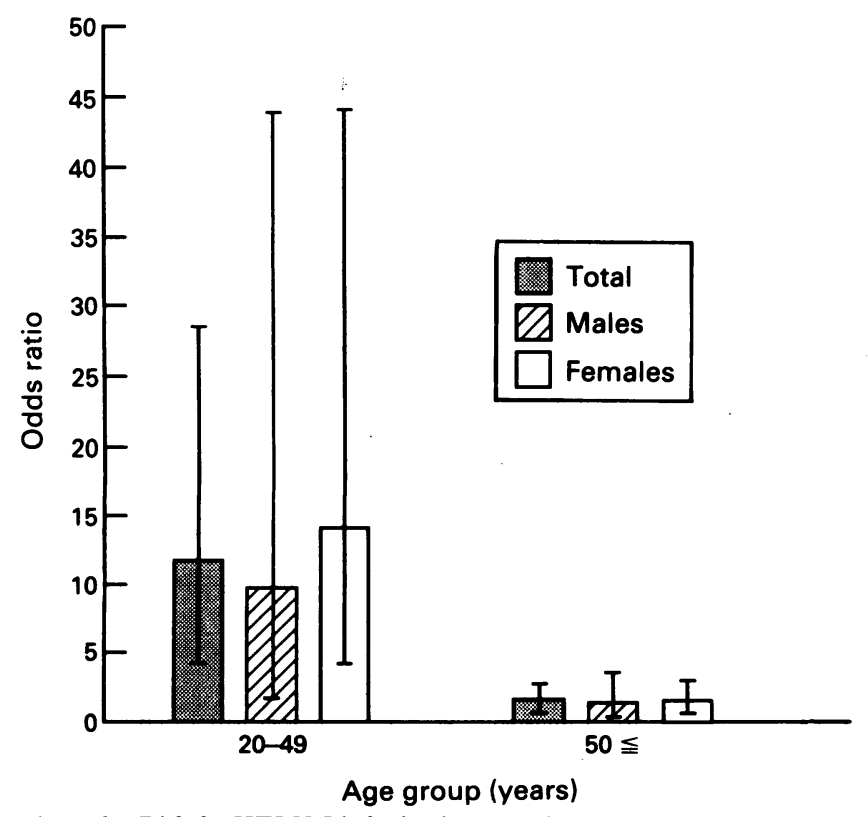

Figure 5 Risk for HTLV-I infection in cases of idiopathic uveitis.

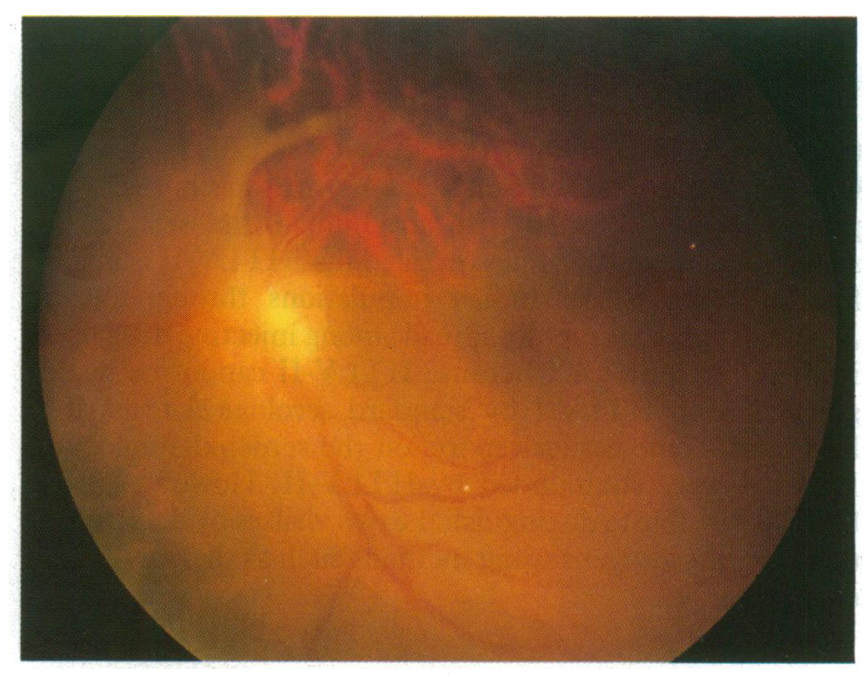

Figure 6 Photograph of HTLV-I uveitis showing membranous vitreous opacities in the left eye of a 25-year-old man (visual acuity 0.6).

ever received a blood transfusion and their husbands were seronegative for HTLV-I, suggesting that the transmission of the virus to the patients was from their mothers, probably via breast feeding.

Although the incidence of ATL and HAM/TSP was reported to be approximately 1 in 1000 to 3000 individuals in the HTLV-I carrier population, ${ }^{45}$ the incidence of HTLV-I uveitis in the carrier population is still unknown.

\section{CLINICAL FEATURES}

The clinical features of idiopathic uveitis in 93 asymptomatic carriers of HTLV-I were analysed..$^{42}$ Even after extensive systemic and ophthalmic examinations and careful determination of the disease history, none of the patients showed evidence of any other uveitis with defined causes, except for the seropositivity to HTLV-I. Therefore, the patients were diagnosed as having HTLV-I uveitis. The age of the onset of uveitis distributed from 19 years to 75 years and the mean age (SEM) was $46.0(3 \cdot 1)$ years. The symptoms at the initial presentation were sudden onset of floaters in $44 \%$ of patients, foggy vision in $43 \%$, and blurred vision in $23 \%$. The inflammation was unilateral in $55 \%$ and bilateral in $45 \%$. The ocular signs of the 93 patients consisted of iritis (96\%), vitreous opacities $(87 \%)$, retinal vasculitis $(70 \%)$, and retinal exudates and haemorrhages $(13 \%)$. As for the anatomical diagnosis of uveitis according to the criteria of the International Uveitis Study Group, ${ }^{46} 13$ patients (14\%) had an anterior uveitis and 56 patients $(60 \%)$ had an intermediate uveitis in which the vitreous opacities (fine cells and lacework-like membranous opacities) were the most impressive findings and were accompanied by mild iritis and mild retinal vasculitis but no uveoretinal lesions. Two patients (2\%) had a posterior uveitis and 22 patients $(24 \%)$ had a panuveitis. An example of HTLV-I uveitis is shown in Figure 6. The visual prognosis of the 93 patients with HTLV-I uveitis was good: 76 of 120 eyes $(63 \%)$ in the 85 patients with long follow up had good visual acuity (20/25 or better) after therapy with topical and/or systemic corticosteroids, 29 eyes (24\%) had fairly good visual acuity (worse than 20/25 but better than $20 / 60)$, and 15 eyes (13\%) had poor visual acuity ( $20 / 60$ or worse). However, the uveitis recurred in about one half of the patients when the therapy was discontinued. These clinical features of HTLV-I uveitis were compared with those in 222 seronegative patients with idiopathic uveitis. ${ }^{42}$ The HTLV-I uveitis group had significantly more female patients, higher incidence of floaters as initial symptoms, higher incidence of vitreous opacities and retinal vasculitis as ocular signs, more patients with an intermediate uveitis and 
fewer patients with an anterior uveitis, and better visual prognosis than those in the seronegative group.

An interesting observation in the HTLV-I uveitis patient group was an association with previously diagnosed Graves' disease. ${ }^{41}$ Sixteen of 93 patients with HTLV-I uveitis (17\%) had a previous history of Graves' disease; 15 patients were female $(15 / 60,25 \%$ of females) and one was male $(1 / 33,3 \%$ of males). Interestingly, uveitis occurred after the onset of Graves' disease in all cases. On the other hand, none of 222 seronegative patients with idiopathic uveitis had a history of Graves' disease. Reasons for the correlation between HTLV-I uveitis and Graves' disease are not yet known, but this finding suggests that some immune mediated mechanisms are involved in HTLV-I uveitis.

\section{MOLECULAR BIOLOGICAL ASPECTS}

The cells floating in the anterior chamber of the eye with HTLV-I uveitis consisted of CD3 lymphocytes (>95\%) with a small proportion of macrophages. There were no malignant cells detected. Using these cells in the aqueous humour, the presence of HTLV-I infected cells at the local site of ocular inflammation was examined by polymerase chain reaction (PCR). ${ }^{36}$ HTLV-I proviral DNA was detected in all nine tested samples from the patients by PCR with pol and/or gag primers. Conversely, the proviral DNA was not detected in any tested samples from seronegative patients with other types of uveitis. Additionally, the proviral DNA was not detected in two seropositive patients (one with toxoplasmosis and the other with Behçet's disease) with uveitis from defined causes. These data thus indicate that HTLV-I infected cells are present at the local site of ocular inflammation in those cases where HTLV-I is the aetiological factor. Furthermore, expression of viral mRNA was detected by reverse transcriptase PCR from the inflammatory cells in the aqueous humour in two of the tested patients with HTLV-1 uveitis (paper in preparation). This indicates that the HTLV-I infected cells play an active role in the pathophysiology and pathogenesis of the uveitis. A quantitative assay of HTLV-I infected cells by PCR revealed that the number of HTLV-I infected cells in the peripheral blood in patients with HTLV-I uveitis was 4 $10 \%$ of peripheral mononuclear cells, which was intermediate between the values in asymptomatic carriers and HAM/TSP patients $(0 \cdot 1 \%$ and $10-20 \%$, respectively; paper in preparation).

\section{IMMUNOLOGICAL ASPECTS}

The antibody level to HTL V-I in 93 patients with HTLV-I uveitis varied from 1:64 to $1: 8192$ by particle agglutination assay and these levels were similar to those of HTLV-I asymptomatic carriers but lower than those of HAM/TSP patients. ${ }^{39}$ The antibody to the virus in the aqueous humour was also detected from all tested samples in patients with HTLV-I uveitis. ${ }^{39}$ The surface phenotype of peripheral lymphocytes in patients with HTLV-I uveitis was analysed with a laser flow cytometry system using monoclonal antibodies to surface markers of lymphocytes and compared with those in seronegative patients with idiopathic uveitis: the CD4 fraction was elevated $(42 \cdot 7 \%(11 \cdot 5 \%) v 30.9 \%(9 \cdot 5 \%)$; $\mathrm{p}<0.01)$ and the CD8 fraction was lowered $(25 \cdot 5 \%(5 \cdot 2 \%) v$ $34.3 \%(10.5 \%) ; \mathrm{p}<0.01)$, thereby elevating the CD4/8 ratio $(1.7(0.6) v 1.0(0.4) ; \mathrm{p}<0.01)$ in the HTLV-I uveitis group compared with the seronegative group. ${ }^{42}$ Furthermore, the CD25 fraction of $T$ lymphocytes, which represents activated $\mathrm{T}$ lymphocytes with expression of interleukin 2 receptors on the cell surface, was significantly elevated in patients with HTLV-I uveitis $(2.5 \%(5.7 \%) v 1.2 \%(0.8 \%) ; \mathrm{p}<0.05){ }^{42}$ The levels of soluble interleukin 2 receptors (sIL2R or sCD25) in the serum were also significantly higher in patients with HTLV-I uveitis than in seronegative healthy controls. ${ }^{39}$ These immunological data thus suggest that the immune mediated mechanisms, particularly by CD4 T lymphocytes, play a role in the pathophysiology of HTLV-I uveitis.

\section{Summary}

The human retroviruses, HTLV-I and HIV, are playing clinically important roles in a variety of ocular disorders, particularly in uveitis. Both viruses are integrated in the genome of infected T cells. HIV-I infection causes the death of the infected $\mathrm{T}$ cells, thereby affecting the host defence system and causing AIDS. Subsequent opportunistic infections of ocular tissues, such as CMV retinitis, are a serious problem in clinical ophthalmology all over the world. Another human retrovirus, HTLV-I, has been known as the causative agent of $T$ cell malignancies (ATL and $T$ cell lymphoma) and chronic myelopathy (HAM/TSP), and is now recognised as a causative agent for a specific type of intraocular inflammation characterised by vitreous opacities with mild iritis and mild retinal vasculitis (HTLV-I uveitis). The mechanism by which HTLV-I causes uveitis is still unknown, but our recent data suggest that it is most probably an immune mediated mechanism by activated CD4 $\mathrm{T}$ cells infected with the virus. HTLV-I uveitis, therefore, may implicate a significant role of retroviruses in autoimmune diseases and further the pathogenesis of diseases with infection/autoimmune overlap.

The authors are grateful to Farley R Cleghorn, MD, MPH, Viral Epidemiology Branch, National Cancer Institute, National Institutes of Health, Bethesda, Maryland, USA, for valuable discussions.

MANABU MOCHIZUKI

Department of Ophthalmology,

Kurume University School of Medicine,

67 Asashi-machi, Kurume, Fukuoka 830, Japan

KAZUO TAJIMA

Division of Epidemiology

Aichi Cancer Center Research Institute,

Kanoko-den, Chikusa-ku, Nagoya 464, Japan

Department of Pathology,

Institute of Medical Science,

University of Tokyo,

Shiroganedai, Minato-ku, Tokyo 108, Japan

Department of Internal Medicine,

Kumamoto University Medical School

Honjo, Kumamoto 860, Japan

TOSHIKI WATANABE

KAZUNARI YAMAGUCHI

1 de The G, HTLV-I and chronic progressive encephalomyelopathies: an immunovirological perspective. HTLV-I and the nervous system. New York: immunovirological perspec

2 Poiesz BJ, Ruscetti FW, Gazdar AF, Bunn PA, Minna JD, Gallo RC. Detection and isolation of type-C retrovirus particules from fresh and cultured lymphocytes of patients with cutaneous T-cell lymphoma. Proc Natl Acad Sci USA 1980: 77: 7415-9.

3 Tajima K, Tominaga S, Kuroishi T, Shimizu H, Suchi T. Geographical features and epidemiological approach to endemic T-cell leukemia/ lymphoma in Japan. Fpn F Clin Oncol 1979; 9 (Suppl 1): 495-504

4 Hinuma Y Nata K Hanaoka M Naki M Matsumoto T, Kinoshita K, et al.

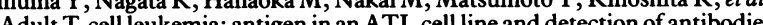
Adult T-cell leukemia: antigen in an ATL cell line and detection of antibodies to the antigen in human sera. Proc Natl Acad Sci USA 1981; 78: 6476-80.

5 Miyoshi I, Kubonishi I, Yoshimoto S, Akagi T, Ohtsuki Y, Shiraishi Y, et al. Type $C$ virus particules in a cord $T$-cell line derived by co-cultivating norma human cord leucocytes and human leukaemia T-cells. Nature 1981; 294: $770-1$

6 Popovic M, Reis MS Jr, Sarngadharan MG, Robert-Guroff M, Kalyanaraman VS, Nakao Y, et al. The virus of Japanese adult T-cell leukemia is a member of the human T-cell leukemia virus group. Nature 1982; 300: 63-6.

7 Watanabe T, Seiki M, Yoshida M. HTLV type I (US isolate) and ATLV (Japanese isolate) are the same species of human retrovirus. Virology 1984; 69: 1255-8.

8 Takatsuki K, Yamaguchi I, Watanabe T, Mochizuki M, Kiyokawa T, Mori S, et al. Adult T-cell leukemia and HTLV-I related diseases. Advances in adult et al. All leukemia and HTL V-I research. Tokyo: Japan Scientific Societies Press, 1992: 1-15.

9 Gessain A Barin F, Vernant JC, Gout O, Maurs L, Calender A, et al. Antibodies to human T-lymphotropic virus type I in patients with tropical Antibodies to human T-lymphotropic virus

10 Rodgers-Johnson P, Gajdusek DC, Morgan OS, Zaninovic V, Sarin PS Graham DS. HTLV-I and HTLV-III antibodies and tropical spastic paraparesis. Lancet 1985; ii: 1247-8.

11 Osame M, Usuku K, Izumo S, Ijichi A, Amitani H, Tara M, et al. HTLV-I associated myelopathy, a new clinical entity. Lancet 1986; i: 1031-2. 
12 Bhagavati S, Ehrich G, Kula R, Kwok S, Sninsky J, Udani V, et al. Detection of human T-cell lymphoma/leukemia virus type I DNA and antigen in spinal fluid and blood of patients with chronic progressive myelopathy. $N \mathrm{Engl} \mathcal{F}$ Med 1988; 318: 1141-7.

13 Jacobson S, Raine CS, Mingioli ES, McFarlin DE. Isolation of an HTLV-I-like retrovirus from patient with tropical spastic paraperesis. Nature 1988; 331: 540.

14 Osame M, Matsumoto M, Usuku K, Izumo S, Ijichi N, Amitani H, et al. Chronic progressive myelopathy associated with elevated antibodies to human T-lymphotropic virus type I and adult T-cell leukemia-like cells. Ann Neurol 1987; 21: 117-22.

15 Nishimoto N, Yoshizaki K, Eiraku N, Machigashira K, Tagoh H, Ogata A et al. Elevated levels of interleukin-6 in serum and cerebrospinal fluid of HTLV-I associated myelopathy/tropical spastic paraparesis. $尹$ Neurol Sci 1990; 97: 183-93.

16 Itoyama Y, Minato S, Kira J, Goto I, Yamamoto N. Increases in helper inducer T cells and activated T cells in HTLV-I associated myelopathy. Ann Neurol 1989; 26: 257-62

17 Itoyama Y, Minato S, Kira J, Goto I, Sato H, Okochi K, et al. Spontaneous proliferation of peripheral blood lymphocytes increased in patients with proliferation of peripheral blood lymphocytes increased in

18 Salahuddin SZ, Markham PD, Lindner SG, Popovic M, Hemmi H, Sarin PS, et al. Lymphokine production by cultured human T cells transformed human T-cell leukemia-lymphoma virus-I. Science 1984; 223 : 703.

19 Osame M, Igata A, Matsumoto M, Kohka M, Usuka K, Isumo S. HTLV-I associated myelopathy (HAM), treatment trials, retrospective survey and clinical and laboratory findings. Hematol Rev $1990 ;: 271-84$.

20 Yoshida M, Osame M, Usuku K, Matsumoto M, Igata A. Viruses detected in HTLV-I associated myelopathy (HAM) and adult T-cell leukemia (ATL) are identical in DNA blotting assay. Lancet 1987; i: 1085-6.

21 Tsujimoto A, Teruchi T, Imamura J, Shimotohno K, Miyoshi I, Miwa M. Nucleotide sequence analysis of a provirus derived from HTLV-I associated myelopathy (HAM). Mol Biol Med 1988; 5: $29-42$.

22 Bartholomew C, Cleghorn F, Charles W, Ratan P, Roberts L, Maharaj K, et al. HTLV-I and tropical spastic paraparesis. Lancet 1986; ii: 99-100.

23 Kawano F, Tsukamoto A, Satoh M, Shido T, Asou N, Takatsuki K. HTLVassociated myelopathy/tropical spastic paraparesis with adult $\mathrm{T}$-cel leukemia. Leukemia 1992; 6: 66-7.

24 Bartholomew C, Saxinger WC, Clark JW, Gail M, Dudgeon A, Mahabir B et al. Transmission of HTLV-I and HIV among homosexual men in Trinidad. FAMA 1987; 257: 2604-8.

25 Tajima K, Hinuma Y. Epidemiology of HTLV-I/II in Japan and the world Advances in adult T-cell leukemia and HTLV-I research. Tokyo: Japan Acientific Societies Press, 1992: 129-49.

26 Kalyanaraman VS, Sarngadharan MG, Robert-Guroff M, Miyoshi I, Blayney $\mathrm{D}$, Golde D, et al. A new subtype of human T-cell leukemia virus (HTLV-II) D, Golde D, et al. A new subtype of human T-cell leukemia virus (HTLV-II) associated

27 Lairmore MD, Jacobson S, Gracia F, De BK, Castillo L, Larreategui M, et al. Isolation of human T-cell lymphotropic virus type 2 from Guaymi Indians in Panama. Proc Natl Acad Sci USA 1990; 87: 8840-4.

28 Lee H, Swanson P, Shorty VS, Zack JA, Rosenblatt JD, Chen ISY. High rate of HTLV-II infection in seropositive IV drug abusers in New Orleans. Science $1990 ; 244: 471-5$.
29 Ohba N, Matsumoto M, Sameshima Y, Kabayama Y, Nakao K, Unoki K, et al. Ocular manifestations in patients infected with human $\mathrm{T}$-lymphotropic virus type I. Fpn f Ophthalmol 1989; 33: 1-12.

30 Nakao K, Ohba N, Isashiki M, Isashiki Y, Unoki K, Osame M. Pigmentary retinal degeneration in patients with HTLV-I-associated myelopathy. Fpn f Ophthalmol 1989; 33: 383-91.

31 Nakao K, Ohba N, Matsumoto M. Noninfectious anterior uveitis in patients infected with human T-lymphotropic virus type I. fpn f Ophthalmol 1989; 33: 472-81.

32 Sasaki K, Morooka I, Inomata H, Akamine T, Osame M. Retinal vasculitis in human T-lymphotropic virus type I associated myelopathy. Brf Ophthalmol 1989; 73: 812-5.

33 Kohno T, Arita T, Okamoto R. Ocular manifestations in human T-lymphotropic virus type I infection. Folia Ophthalmol fpn 1990; 41: 2182-8.

34 Ishimoto S, Sakai Y, Ishibashi T, Khono T, Inomata H, Itoyama Y. Interferon-a for the treatment of retinal vasculitis associated with human T-lymphotropic virus type I myelopathy (HAM). Acta Soc Ophthalmol fpn 1990; 94: 769-73.

35 Nakao K, Matsumoto M, Ohba N. Seroprevalence of antibodies to HTLV-I in patients with ocular disorders. BrF Ophthalmol 1991; 75: 76-8.

36 Mochizuki M, Watanabe T, Yamaguchi K, Takatsuki K, Yoshimura K, Shirao $M$, et al. HTLV-I uveitis: a distinct clinical entity caused by HTLV-I. Fpn f Cancer Res 1992; 83: 236-9.

37 Mochizuki M, Yamaguchi K, Tasatsuki K, Watanabe T, Mori S, Tajima K. HTLV-I and uveitis. Lancet 1992; i: 1110

38 Mochizuki M, Watanabe T, Yamaguchi K, Yoshimura K, Nakashima S, Shirao M, et al. Uveitis associated with human T-cell lymphotropic virus type I. Am f Ophthalmol 1992; 114: 123-9.

39 Mochizuki M, Watanabe T, Yamaguchi K, Tajima K, Yoshimura K, Nakashima S, et al. Uveitis associated with human T lymphotropic virus type I: seroepidemiological, clinical, and virological studies. F Infect Dis 1992; 166: $943-44$.

40 Araki S,Mochizuki M, Yamaguchi K, Watanabe T, Ono A, Yoshimura K, et al. Familial clustering of human $\mathrm{T}$ lymphotropic virus type I uveitis. et al. Familial clustering of hum

41 Yamaguchi K, Mochizuki M, Watanabe T, Yoshimura K, Shirao M, Araki S, et al. Human T lymphotropic virus type 1 uveitis after Graves' disease. $\mathrm{Br} F$ Ophthalmol 1994 (in press)

42 Yoshimura K, Mochizuki M, Araki S, Miyata N, Yamaguchi K, Tajima K, et al. Clinical and immunological features of human $\mathrm{T}$-cell lymphotropic virus type I uveitis. Am 7 Ophthalmol 1993; 116: 156-63.

43 Tachibana N, Okayama A, Kusune E, Yokota T, Shishime E, Tsuda K. Antihuman T-cell leukemia virus antibody distribution in Miyazaki Prefecture. f $\mathcal{F p n}_{\text {Infect }}$ Dis 1984; 58: 717-22.

44 Tajima K, Kamura S, Ito S, Ito M, Nagatomo M, Kinoshita K, et al. Epidemiological features of HTLV-I carriers and incidence of ATL in an ATL-endemic island: a report of the community-based cooperative study in Tsushima, Japan. Int $f$ Cancer 1987; 40: 741-6.

45 Kondo T, Kono H, Miyamoto N, Yoshida R, Toki H, Matsumoto I, et al. Ageand sex-specific cumulative rate and risk of ATLL for HTLV-I carriers. Int $\mathcal{F}$ Cancer 1989; 43: 1061-4.

46 Bloch-Michel E, Nussenblatt RB. International uveitis study group recommendations for the evaluation of intraocular inflammatory disease. Am F Ophthalmol 1987; 103: 234-5. 